\title{
ANALISIS KEMAMPUAN BERPIKIR KREATIF MATEMATIS DITINJAU DARI SELF-CONCEPT MATEMATIS SISWA
}

\author{
Siska Susilawati ${ }^{1}$, Heni Pujiastuti ${ }^{2}$, Sukirwan $^{3}$ \\ ${ }^{1,2,3}$ Universitas Sultan Ageng Tirtayasa \\ henipujiastuti@untirta.ac.id
}

\begin{abstract}
The ability to think creatively in students personally, will make learning mathematics that is considered difficult gradually will be a fun lesson because by creative thinking students can solve problems in their own way without thinking focused on a solution. In addition to cognitive abilities, there are other factors that can affect one's learning process, namely affective abilities, one of which is self-concept. Self-concept is a very important ability possessed by every student because it will make students more confident in working on problems and being serious in learning mathematics. This research was conducted to describe students 'abilities in mathematical creative thinking in terms of students' mathematical self-concepts. This type of research is a descriptive study with a qualitative approach. The subjects of this study were students of MTsN 1 Serang. The procedure of this research includes the preparation stage, the implementation phase, the data analysis stage, and the report preparation stage. In this study there are students who possess mathematical selfconcept which is inversely proportional to the results of their mathematical creative thinking abilities. There are students who have high self-concept but are less creative and there are students who have low self-concept but are categorized as creative.
\end{abstract}

Keywords: Mathematical creative thinking ability, mathematical self-concept

\begin{abstract}
Abstrak
Terbentuknya kemampuan berpikir kreatif pada pribadi siswa, akan membuat pembelajaran matematika yang dianggap sulit bertahap akan menjadi pelajaran yang menyenangkan, karena dengan berpikir kreatif siswa dapat menyelesaikan permasalahan dengan cara sendiri tanpa adanya pemikiran yang terfokuskan dengan satu penyelesaian. Selain kemampuan kognitif, ada faktor lain yang bisa mempengaruhi proses pembelajaran seseorang yaitu kemampuan afektif salah satunya self-concept. Self-concept merupakan kemampuan yang sangat penting dimiliki setiap siswa karena akan menjadikan siswa lebih percaya diri dalam mengerjakan soalsoal dan bersungguh-sungguh dalam belajar matematika. Penelitian ini dilakukan untuk mendeskripsikan kemampuan siswa dalam berpikir kreatif matematis yang ditinjau dari self-concept matematis siswa. Jenis penelitian ini adalah penelitian deskriptif dengan pendekatan kualitatif. Subjek penelitian ini adalah siswa MTsN 1 Kota Serang. Prosedur penelitian ini meliputi tahap persiapan, tahap pelaksanaan, tahap analisis data, dan tahap penyusunan laporan. Pada penelitian ini terdapat siswa yang memliki self-concept matematis yang berbanding terbalik dengan hasil tes kemampuan berpikir kreatif matematisnya. Terdapat siswa yang selfconcept tinggi namun kurang kratif dan adapaun siswa yang self concept rendah namun termasuk katagori kreatif.
\end{abstract}

Kata kunci: Kemampuan Berpikir Kreatif Matematis, Self-Concept Matematis

\section{PENDAHULUAN}

Pengembangan berpikir kreatif merupakan salah satu fokus utama dalam dunia pendidikan matematika modern. Hal ini disebabkan karena berpikir kreatif merupakan salah satu kemampuan yang saat ini dikehendaki dalam dunia kerja. Individu yang diberi kesempatan berpikir kreatif akan tumbuh sehat dan mampu menghadapi tantangan. Sebaliknya, individu yang tidak diperkenankan berpikir kreatif akan menjadi frustasi dan tidak puas (Hanipah, et al, 2018). Berpikir kreatif secara umum dan dalam matematika merupakan bagian keterampilan hidup yang sangat diperlukan siswa dalam menghadapi kemajuan IPTEKS yang semakin pesat serta tantangan, tuntutan dan persaingan global yang 
Analisis Kemampuan Berpikir Kreatif Matematis Ditinjau Dari Self-Concept Matematis Siswa, Siska Susilawati, Heni Pujiastuti, Sukirwan

semakin ketat. Terbentuknya kemampuan berpikir kreatif pada pribadi siswa, akan membuat pembelajaran matematika yang dianggap sulit bertahap akan menjadi kebalikan bahwa matematika pelajaran yang menyenangkan, karena dengan berpikir kreatif siswa dapat menyelesaikan permasalahan dengan cara sendiri tanpa adanya pemikiran yang terfokuskan dengan satu penyelesaian. Kemampuan berpikir kreatif juga diperlukan untuk menentukan strategi yang tepat dalam menyelesaikan beragam permasalahan matematika dari yang mudah hingga permasalahan yang rumit (Prihatiningsih, et al, 2020)

Siswa dikatakan memiliki kemampuan berpikir kreatif apabila ia memiliki banyak gagasan dan ide, imajinatif, rasa ingin tahu yang tinggi, percaya diri terhadap kemampuannya, positif thinking, selalu menantang terhadap permasalahan yang komplek serta selalu bekerja keras (Hendriana et al, 2017). Dapat dikatakan berpikir kreatif adalah proses yang dilakukan oleh seseorang untuk mengembangkan suatu persoalan menjadi alternatif jawaban dalam memecahkan persoalan-persoalan yang berhubungan dengan logika, pola dan urutan yang sistematis. Dalam pemecahan masalah matematika apabila menerapkan berpikir kreatif, akan menghasilkan banyak ide-ide yang berguna dalam menemukan penyelesaian masalah. Indikator kemampuan berpikir kreatif menurut Guilford yaitu berpikir lancar (fluency), berpikir luwes (flexibility), berpikir orisinil (originality) dan berpikir terperinci (elaboration) (Munandar, 2012).

Kemampuan berpikir kreatif matematis siswa di Indonesia pada kenyataannya tergolong rendah. Berdasarkan penelitian yang dilakukan Hans Jellen dari Universitas Utah, Amerika Serikat dan Klaus Urban dari Universitas Hannover, Jerman menyatakan bahwa dari 8 negara yang diteliti, kreativitas anak-anak Indonesia adalah yang terendah. Berikut berturutturut dari yang tertinggi sampai yang terendah rata-rata skor tesnya adalah: Filipina, Amerika Serikat, Inggris, Jerman, India, RRC, Kamerun, Zulu, dan terakhir Indonesia. Menurut beberapa dugaan, penyebab rendahnya kreativitas anak-anak Indonesia adalah lingkungan yang kurang menunjang anak-anak tersebut untuk mengekspresikan kreativitasnya, khususnya lingkungan keluarga dan sekolah (Rahman, 2012). Rendahnya kemampuan berpikir kreatif juga dapat berimplikasi pada rendahnya pencapaian dan prestasi siswa.

Selain kemampuan kognitif, ada faktor lain yang bisa mempengaruhi proses pembelajaran seseorang yaitu kemampuan afektif salah satunya self-concept. Self-concept merupakan kemampuan yang sangat penting dimiliki setiap siswa karena akan menjadikan siswa lebih percaya diri dalam mengerjakan soal-soal, lebih berani, gigih dan bersungguhsungguh dalam belajar matematika. 
Ritandiyono dan Retnaningsih (Supardi \& Leonard, 2010) menyatakan self-concept bukan merupakan faktor yang dibawa sejak lahir, melainkan faktor yang dipelajari dan terbentuk melalui pengalaman individu dalam berhubungan dengan orang lain. Sejalan dengan hal tersebut, Brooks dalam Rahman (2012) menyatakan bahwa self-concept adalah persepsi tentang diri seseorang yang bersifat fisik, psikologi, maupun sosial sebagai hasil dari pengalaman dan interaksi dengan orang lain. Sudah menjadi suatu kondisi yang alami bahwa setiap manusia mmiliki kemampuan yang berbeda-beda. Hal ini dapat terjadi karena manusia memiliki kemampuan merefleksi dirinya sendiri yang disebut "self-concept".

Self-concept merupakan kemampuan peserta didik dalam mengekspresikan dirinya secara berani dan percaya diri dalam menyelesaikan suatu permasalahan. Pentingnya selfconcept dimiliki oleh peserta didik tertuang dalam KTSP 2006 dan disempurnakan dalam kurikulum 2013 yaitu "dalam aplikasinya, peserta didik diharapkan memiliki sifat menghargai kegunaan matematika yaitu sikap rasa ingin tahu, perhatian, dan minat yang tinggi dalam mempelajari matematika, serta sikap tekun dan percaya diri dalam menyelesaikan permasalahan.” (Hendriana, et al, 2017). Konsep diri (self concept) merupakan suatu bentuk yang teratur mengenai persepsi-persepsi diri. Konsep diri mengandung unsurunsur seperti persepsi individu mengenai karakteristik dan kemampuannya; persepsi dan konsep diri yang berkaitan dengan orang lain dan lingkungannya; kualitas nilai yang dirasa berkaitan dengan pengalaman dirinya dan objek yang dihadapi, dan tujuan serta cita-cita yang dirasa mempunyai nilai positif atau negatif (Rahman, 2012).

Self-concept dibagi menjadi self-concept positif dan negatif. Hurlock (Simanjuntak, 2009) menyatakan bahwa individu dengan konsep diri positif akan mengembangkan sikapsikap seperti kepercayaan diri, harga diri, dan kemampuan untuk melihat dirinya secara realistis. Sebaliknya, self-concept negatif akan menggambarkan perasaan tidak mampu dan rendah diri. Dalam kegiatan pembelajaran matematika di kelas seharusnya siswa memiliki self-concept positif. Namun, pada kenyataannya saat ini sebagian besar siswa menganggap bahwa matematika itu sulit. Hal ini dapat diketahui dari penelitian Coster (Salamor, 2013) yang menyatakan bahwa sebagian besar siswa merasa cemas jika mempelajari matematika. Kecemasan tersebut menyebabkan siswa tidak percaya diri dalam menghadapi masalah matematika. Selain itu, siswa merasa tidak mampu dan menyerah atau bahkan menolak untuk mengerjakan soal matematika didepan kelas.

Persepsi yang baik akan berdampak positif terhadap kemajuan belajar peserta didik, akan tetapi persepsi yang kurang baik dapat menghambat proses pembelajaran yang dilakukan, dalam hal ini peserta didik diharapkan dapat membentuk persepsi dan perasaan 
Analisis Kemampuan Berpikir Kreatif Matematis Ditinjau Dari Self-Concept Matematis Siswa, Siska Susilawati, Heni Pujiastuti, Sukirwan

yang positif dengan cara mengevaluasi segala kekurangannya dan berusaha untuk mengurangi persepsipersepsi dan perasaan negatif terhadap diri sendiri. Berdasarkan hal yang dikemukakan di atas, maka dapat disimpulkan bahwa self-concept adalah persepsi seseorang terhadap dirinya, lingkungan, dan kemampuan - kemampuan yang dimilikinya.

Berdasarkan hasil penelitian yang telah dilakukan oleh Siti Romlah dan Chandra Novtiar (2018) menyimpulkan bahwa semakin baik self-concept yang dimiliki siswa maka akan semakin tinggi juga kemampuan berpikir kreatif matematisnya. Kesimpulan yang sama didapatkan dari hasil penelitian yang dilakukan oleh nurul dan luvy (2018) yaitu kemampuan berpikir kreatif matematis siswa yang rendah diikuti dengan self-concept yang rendah pula sehingga dapat dikatakan bahwa terdapat hubungan yang kuat antara kemampuan berpikir kreatif matematis dengan self-concept siswa.

\section{METODE}

Jenis penelitian ini adalah penelitian deskriptif dengan pendekatan kualitatif. Penelitian ini dilakukan untuk mendeskripsikan kemampuan siswa dalam berpikir kreatif matematis pada materi Bangun Ruang Sisi Datar yang ditinjau dari self-concept matematis siswa. Subjek penelitian ini adalah siswa MTsN 1 Kota Serang kelas VIII A tahun ajaran 2019/2020. Dalam penelitian ini peneliti memberikan instrumen test berupa soal kemampuan berpikir kreatif matematis untuk mengetahui kemampuan berpikir kreatif matematis siswa pada materi bangun ruang sisi datar dan memberian instrumen non-tes berupa angket selfconcept serta wawancara kepada beberapa siswa. Setelah didapat hasil angket self-concept matematis siswa maka siswa dikelompokkan menjadai 3 katagori yaitu katagori 'self-concept rendah', 'self-concept sedang', dan 'self-concept tinggi'. Didapat 3 kelompok siswa berdasarkan self-concept matematis yang dimilkinya, dari 3 kelompok tersebut masingmasing di analisis hasil tes kemampuan berpikir kreatifnya apakah termasuk kedalam katagori sangat kreatif, kreatif, cukup kreatif atau kurang kreatif. Prosedur penelitian ini meliputi empat tahap diantaranya tahap persiapan, tahap pelaksanaan, tahap analisis data, dan tahap penyusunan laporan.

Analisis data dalam penelitian ini meliputi beberapa tahap yaitu data reduction, conclusion, dan drawing/verification. Analisis data dalam penelitian kualitatif dilakukan pada saat pengumpulan data berlangsung, dan selesai pengumpulan data. Bogdan menyatakan analisis data kualitatif adalah proses mencari dan menyusun secara sistematis data yang diperoleh dari hasil wawancara, catatan lapangan, dan bahan-bahan lainnya sehingga dapat mudah dipahami, dan temuannya dapat diinformasikan kepada orang lain (Sugiyono, 2017). 
Tes kemampuan berpikir kreatif matematis dilakukan pada tanggal 7 April 2020 secara online dikarena sekolah diberlakukan secara online dari rumah dalam rangka pencegahan wabah virus covid-19. Dalam penelitian ini untuk mengukur self-concept siswa terhadap matematika digunakan indikator menurut Calhoun dan Accocella (1995).

\section{Tabel 1.}

Indikator Self-Concept Siswa

\begin{tabular}{|l|c|l|}
\hline No & Dimensi & \multicolumn{1}{c|}{ Indikator } \\
\hline 1 & Pengetahuan & $\begin{array}{l}\text { Pandangan siswa terhadap kemampuan matematika yang } \\
\text { dimilikinya }\end{array}$ \\
\hline 2 & Harapan & $\begin{array}{l}\text { Pandangan siswa tentang gambaran diri ideal atau kemampuan } \\
\text { matematika ideal yang ingin dimilikinya. }\end{array}$ \\
\hline 3 & \multirow{2}{*}{ Penilaian } & $\begin{array}{l}\text { Pandangan siswa tentang hubungan antara kemampuan yang } \\
\text { dimilikinya (dimensi pengetahuan) dengan kemampuan } \\
\text { matematika ideal yang dimilikinya. }\end{array}$ \\
\cline { 3 - 4 } & $\begin{array}{l}\text { Pandangan siswa tentang bagaimana orang lain memandang } \\
\text { dirinya. }\end{array}$ \\
\cline { 3 - 4 } & $\begin{array}{l}\text { Penilaian siswa terhadap dirinya apakah ia termasuk sebagai } \\
\text { orang yang relatif sukses atau relatif gagal dalam } \\
\text { belajar matematika. }\end{array}$ \\
\hline
\end{tabular}

Adapun instrumen lainnya dalam penelitian ini yaitu tes kemampuan berpikir kreatif matematis dengan karakteristik indikator berpikir kreatif sebagai berikut:

Tabel 2.

Karakteristik indikator kemampuan berpikir kreatif

\begin{tabular}{|l|l|}
\hline \multicolumn{1}{|c|}{ Aspek yang diukur } & \multicolumn{1}{c|}{ Respon siswa terhadap soal } \\
\hline Kelancaran (Fluency) & $\begin{array}{l}\text { Siswa mampu menjawab jika ada pertanyaan dan lancar } \\
\text { mengungkapkan gagasan -gagasannya. }\end{array}$ \\
\hline Keluwesan (Flexibility) & $\begin{array}{l}\text { Siswa menghasilkan jawaban yang seragam, tetapi dengan } \\
\text { arah pemikiran (melalui cara) yang berbeda }\end{array}$ \\
\hline Keaslian (Oiginality) & $\begin{array}{l}\text { Siswa memberikan jawaban yang lain dari yang lain, yang } \\
\text { jarang diberikan kebanyakan orang (menjawab dengan } \\
\text { cara/idenya sendiri) }\end{array}$ \\
\hline Kerincian (Elaboration) & $\begin{array}{l}\text { Siswa dapat menemukan arti yang lebih mendalam terhadap } \\
\text { pemecahan masalah dengan menggunakan langkah-langkah } \\
\text { yang terperinci }\end{array}$ \\
\hline
\end{tabular}

\section{HASIL}

Angket self-concept matematis merupakan suatu tes yang digunakan untuk mengetahui self-concept matematis dimiliki oleh siswa. Pemberian tes self-concept matematis dilakukan dikelas VIII A dengan jumlah siswa sebanyak 38 siswa. Siswa diberikan angket berisi 30 pernyataan berkaitan dengan konsep diri berdasarkan dimensi pengetahuan, 
penilaian, dan harapan. Selanjutnya siswa dikelompokkan dalam 3 tingkatan yaitu selfconcept tinggi, self-concept sedang, dan self-concept rendah. Adapun hasil self-concept matematis yang dimiliki oleh siswa adalah sebagai berikut.

\section{Tabel 3.}

Hasil Tes Self-Concept Matematis Siswa

\begin{tabular}{ccc}
\hline Kriteria & Jumlah & Keterangan \\
\hline $1,00-3,69$ & 4 & Rendah \\
$3,70-6,39$ & 23 & Sedang \\
$6,40-9,00$ & 11 & Tinggi \\
\hline
\end{tabular}

Berdasarkan tabel 3 dapat kita ketahui bahwa hasil tes self-concept matematis siswa kelas VIII A dominan memiliki katagori sedang yaitu terdapat 23 siswa (61\%) memiliki selfconcept matematis, sedangkan ada $4(10 \%)$ siswa yang termasuk kedalam kriteria selfconcept matematis rendah dan 11 (29\%) siswa termasuk kedalam kriteria self-Concept matematis tinggi.

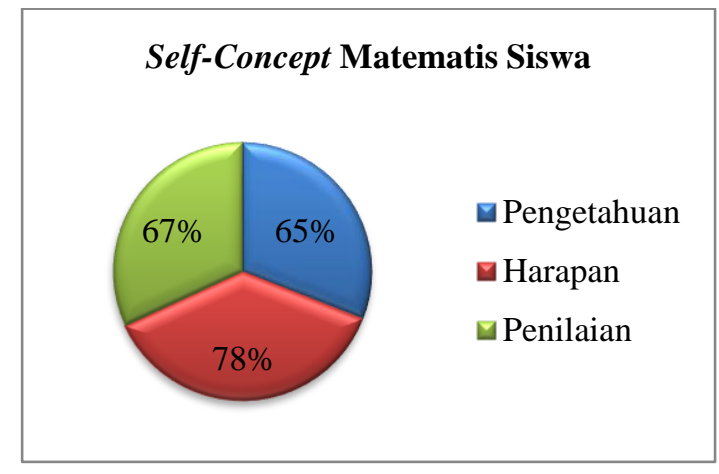

Gambar 1. Presentase Indikator Self-Concept Matematis Siswa

Terlihat dari Gambar 1 bahwa dari hasil angket didapat $67 \%$ siswa mempunyai penilaian yang positif, ini artinya pandangan siswa tentang hubungan antara kemampuan yang dimilikinya (dimensi pengetahuan) dengan kemampuan matematika ideal yang dimilikinya cukup tinggi dan rata-rata siswa mempunyai pandangan terhadap dirinya sebagai orang yang relatif sukses dalam belajar matematika. Hal ini menggambarkan bahwa siswa mempunyai kepercayaan diri yang cukup tinggi dalam pembelajaran matematika. Pada indikator pengetahuan dari hasil angket self-concept matematis rata-rata siswa memiliki pandangan yang cukup tinggi (65\%) terhadap kemampuan matematika yang dimilikinya. Hal ini sejalan dengan indikator penilaian karena ada kaitan yang erat antara indikator pengetahuan dengan indikator penilaian yaitu ketika siswa menilai bahwa dia sukses atau mampu dalam pembelajaran maka hal itu didasarkan dengan pengetahuannya mengenai 
kemampuan yang dia miliki. Pada diagram 1 terlihat bahwa tingginya presentasi indikator harapan dari hasil tes self-concept matematis siswa, hal ini gambaran bahwa siswa memiliki harapan yang tinggi terhadap kemampuan matematis yang dimilikinya.

Setelah siswa dikelompokkan menjadi 3 katagori yaitu katagori self-concept rendah, self-concept sedang dan self-concept tinggi, masing-masing katagori dilihat dan dianalisis kemampuan berpikir kreatif matematisnya berdasarkan hasil tes kemampuan berpikir kreatif matematis yang telah diberikan. Sebelas siswa yang termasuk katagori self-concept tinggi dari 38 rata-rata hasil tes kemampuan berpikir kreatifnya 'cukup kreatif'.

Pada siswa yang memiliki self-concept matematis tinggi dengan jumlah siswa 11 orang, rata-rata skor hasil tes kemampuan berpikir kreatif matematis termasuk kedalam katagori 'cukup kreatif', dengan perolehan skor tertinggi adalah 83 dan perolehan skor terendah adalah 50. Dari katagori self-concept matematis tinggi diambil 2 siswa sebagai subyek penelitian, yaitu 1 siswa dengan kode SGI 3 yang memiliki self-concept tinggi yang termasuk katagori berpikir kreatif 'kurang kreatif' dan 1 siswa dengan kode SGI 26 yang termasuk katagori 'kreatif'.

4. Perhatikan gambar dibawah ini.

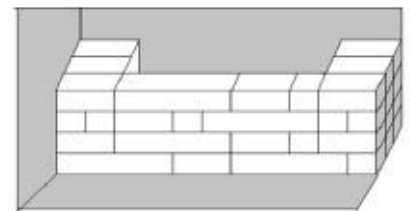

Pak Umar ingin membuat bak mandi di rumahnya berbentuk balok seperti gambar diatas. Panjang bak mandi terdiri dari 2 bata ukuran besar, 1 bata ukuran sedang, dan satu bata ukuran kecil, sedangkan lebar bak mandi terdiri dari 3 bata ukuran sedang dan tinggi 4 bata ukuran sedang. Jika seluruhnya digunakan bata ukuran kecil, berapa banyak bata ukuran kecil yang digunakan untuk membuat bak mandi tersebut? Jelaskan langkahlangkahnya.

Gambar 2. Soal Kemampuan Berpikir Kreatif Matematis Nomor 4.

Kemampuan siswa dalam menyelesaikan permasalahan pada soal nomor 4 tersebut merupakan salah satu wujud dari siswa yang memenuhi indikator kerincian (elaboration). Indikator tersebut menggambarkan bahwa siswa dapat menemukan arti yang lebih mendalam terhadap pemecahan masalah dengan menggunakan langkah-langkah yang terperinci. Berikut ini merupakan jawaban siswa yang memperoleh skor tertinggi yaitu siswa yang diberi kode SGI 26. Siswa SGI 26 menuliskan penyelesaian secara dengan kemampuannya sendiri dan gagasannya sendiri. 


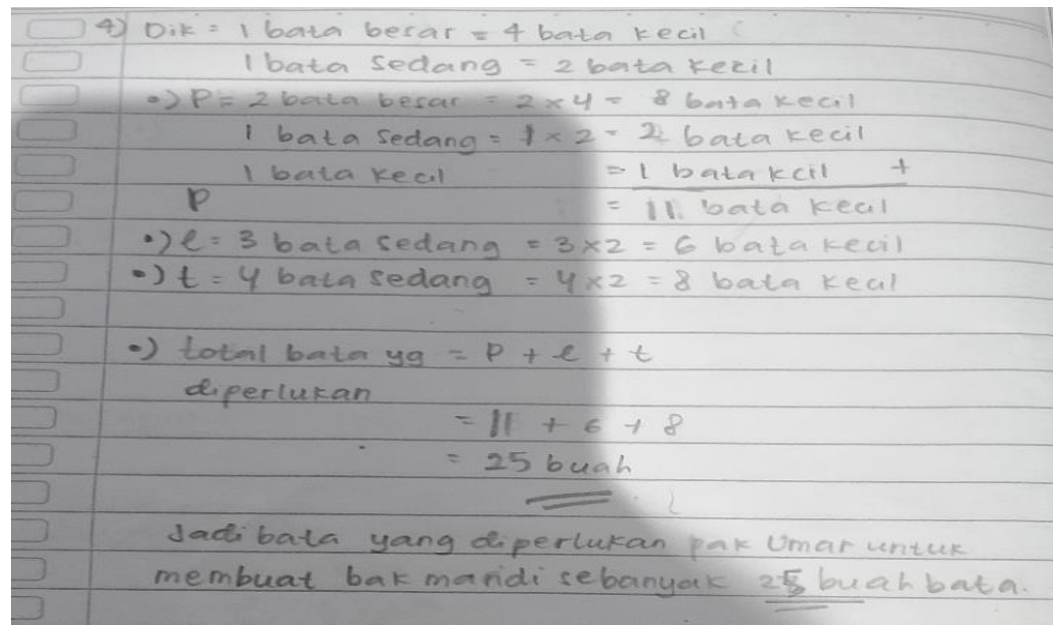

Gambar 3. Jawaban Siswa Kode SGI 26 Pada Nomor 4

Siswa dengan kode SGI 26 juga merupakan salah satu siswa yang menjawab soal nomor 5 dengan benar dan lancar sesuai dengan indikator kelancaran (Fluency) yaitu siswa mampu menjawab soal dengan lancar mengungkapkan gagasan-gagasannya.

5. Sebuah kubus mempunyai panjang rusuk $5 \mathrm{~cm}$ seperti gambar dibawah ini.

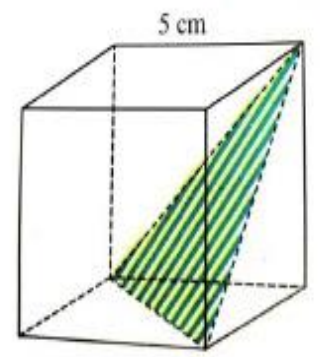

Jika salah satu bagian kubus terebut dipotong dengan bagian potongan tersebut berbentuk limas segitiga (tetrahedron). Tentukan luas permukaan kubus setelah dipotong.

Gambar 4. Soal Kemampuan Berpikir Kreatif Matematis Nomor 5

Siswa SGI 26 menjawab soal nomor 5 dengan menggunakan rumus yang benar dan dengan lancar menggunakan langkah-langkah penyelesain yang menghasilkan hasil akhir dengan benar. Dari hasil angket diketahui siswa kode SGI 26 ini mempunyai penilaian tinggi terhadap kemampuan matematika yang dia miliki sehingga dia dengan percaya diri menjawab soal test kemampuan berpikir kreatif matematis dan siwa mengenali kemampuan yang ada dalam dirinya sendiri sehingga siswa mampu memutuskan suatu gagasan dalam memecahkan permasalahan.

Pada tes kemampuan berpikir kreatif matematis, terdapadat siswa yang diberi kode SGI 5 mempunyai hasil dengan katagori cukup kreatif dan hasil tes self-concept matematis siswa tersebut masuk kedalam katagori cukup. 
1. Perhatikan gambar dibawah ini.

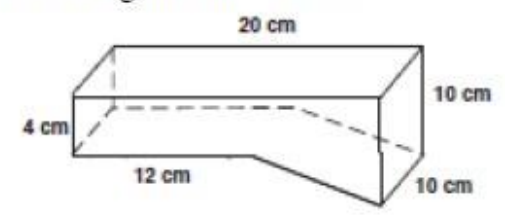

Hitunglah volume bangun ruang diatas. (Pikirkan sedemikian sehingga besar kemungkinan cara/langkah penyelesaian kamu berbeda dengan yang dikerjakan temantemanmu).

\section{Gambar 5. Soal Kemampuan Berpikir Kreatif Matematis Nomor 1}

Siswa dengan kode SGI 5 memiliki jawaban yang berbeda dari yang lain pada soal nomor 1. Walaupun berbeda namun jawaban siswa SGI 5 termasuk jawaban yang benar dengan cara yang rinci dan jelas serta menghasil hasil akhir yang benar. Berikut ini jawaban siswa SGI 5 pada soal nomor 1.

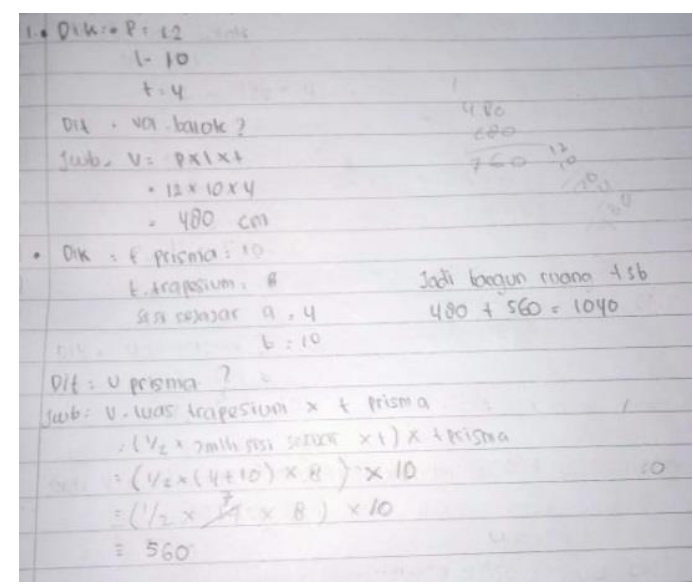

\section{Gambar 6. Jawaban Siswa Kode SGI 5 Pada Nomor 1}

Pada gambar 6 terlihat siswa SGI 5 menjawab soal nomor 1 dengan secara rinci dan jelas. Jawaban tersebut memenuhi indikator Keaslian (Oiginality), yaitu siswa mampu memberikan jawaban yang tidak lazim, lain dari yang lain, dan jawaban jarang diberikan oleh kebanyakan orang dengan cara yang benar dan menghasilkan nilai akhir yang benar.

Pada katagori self-concept matematis yang tinggi dengan kemampuan berpikir kreatif katagori 'cukup kreatif' terdapat salah satu siswa yang diberi kode SGI 15, hasil tes kemampuan berpikir kreatif matematis menunjukkan bahwa siswa SGI 15 memenuhi indikator kerincian (Elaboration), hal ini terlihat jelas pada penyelesaian yang dituliskannya pada soal nomor 4. Hal tersebut menunjukkan bahwa siswa dapat menemukan arti yang lebih mendalam terhadap pemecahan masalah dengan menggunakan langkah-langkah yang terperinci. 


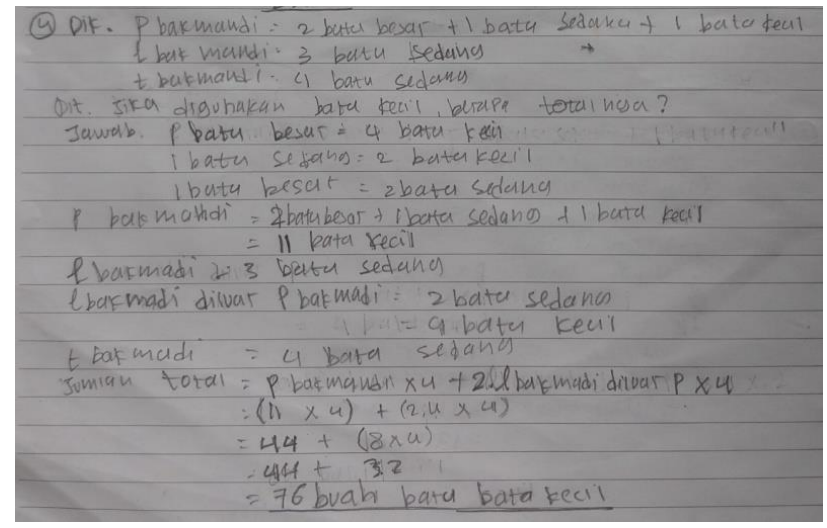

Gambar 7. Jawaban Siswa Kode SGI 15 Pada Nomor 4

Dilihat dari hasil angket self-concept matematis siswa SGI 15 memiliki self-concept matematis yang tinggi. Karena kepercayaan siswa SGI 15 dengan kemampuan matematika yang dimiliki maka dia dapat menuliskan penyelesaian dengan menggunakan langkahlangkah yang terperinci. Namun siswa SGI 15 kurang teliti dalam menghitung serta menuliskan satuan dalam penyelesaian yang dituliskannya. Hal ini tergambarkan dalam wawancara yang dilakukan oleh peneliti dengan siswa SGI 15.

Pada hasil tes kemampuan berpikir kreatif matematis, terdapat salah satu siswa yang masuk kedalam katagori kurang kreatif dan hasil angket self-concept matematis siswa tersebut rendah yang diberi kode siswa SGI 35. Siswa tersebut hanya menjawab 1 nomor pada tes kemampuan berpikir kreatif matematis yang diberikan peneliti. Pada soal nomor 2, yang meminta siswa menuliskan penyelesaian dengan dua cara atau lebih, siswa SGI 35 hanya menjawab dengan satu cara, maka siswa tersebut tidak dapat memenuhi indikator keluwesan (Flexibility) yaitu siswa mampu menghasilkan gagasan-gagasan yang seragam, mampu mengubah cara atau pendekatan dan memiliki arah pemikiran yang berbeda-beda. Dari hasil wawancara yang dilakukan peneliti terhadap siswa SGI 35 menggambarkan bahwa penilaian terhadap kemampuan matematis yang dia miliki tergolong rendah serta siswa tersebut mempunyai harapan terhadap kemampuan matematis untuk dirinya sendiri tergolong rendah.

Hasil tes siswa SGI 25, SGI 5, SGI 15 dan SGI 35 sesuai dengan hasil penelitian yang dilakukan oleh Siti dan Chandra (2018) bahwa semakin baik self-concept yang dimiliki siswa maka akan semakin tinggi juga kemampuan berpikir kreatif matematisnya. Hal ini juga sesuai dengan pernyataan Guilford (Munandar, 2012) yaitu konsep diri yang positif dapat memunculkan kemampuan kreatif. Semakin kuat konsep diri individu, maka kemampuan berpikir kreatif yang dimiliki semakin berkembang. 
Pada penelitian ini menghasilkan sedikit perbedaan dengan penelitian yang telah dilakukan oleh Siti dan Chandra (2018) yaitu kemampuan berpikir kreatif matematis siswa tidak berbanding lurus dengan self-concept matematis yang dimilikinya. Selain itu penelitian ini juga sedikit berbeda dengan hasil penelitian yang dilakukan oleh nurul dan luvy (2019) bahwa kemampuan berpikir kreatif matematis siswa yang rendah diikuti dengan self-concept yang rendah pula sehingga dapat dikatakan bahwa terdapat hubungan yang kuat antara kemampuan berpikir kreatif matematis dengan self-concept siswa. Terdapat siswa yang diberi kode siswa SGI 9 mempunyai self-concept matematis tinggi namun hasil tes kemampuan berpikir kreatifnya rendah. Berikut ini adalah jawaban salah satu siswa yang memiliki hasil tes kemampuan berpikir kreatif yang rendah namun memiliki self-concept matematis dengan katagori tinggi.

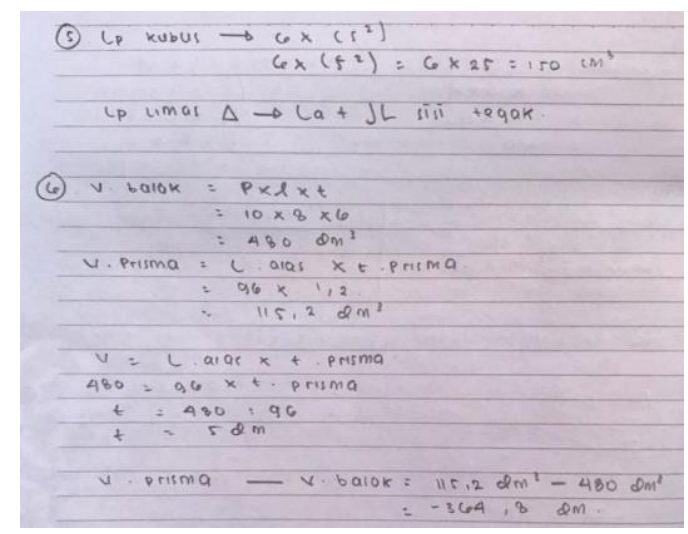

Gambar 8. Jawaban Siswa SGI 9 Pada Soal Nomor 5 dan 6

Terlihat dari jawaban siswa SGI 9 pada nomor 5 dan 6 bahwa siswa kurang teliti dan kurang memahami apa yang dimaksud dari soal yang diberikan. Pada jawaban nomor 5 siswa SGI 9 sudah benar dalam menuliskan rumus apa yang harus dipakai dalam menyesaikan soal namun pada perhitungannya siswa SGI 9 terhenti. Hal ini dapat dikatakan bahwa siswa SGI tidak dapat memenuhi indikator kelancaran (Fluency), yaitu siswa tidak lancar mengungkapkan gagasan-gagasannya. Pada jawaban soal nomor 6 siswa SGI telah menuliskan rumus yang benar serta perhitungannya benar, namun yang dimaksud pada soal nomor 6 tidak seperti apa yang siswa SGI 9 berikan. Hal ini dapat dikatakan bahwa siswa SGI 9 tidak dapat menemukan arti yang lebih mendalam terhadap pemecahan masalah dengan menggunakan langkah-langkah yang terperinci. Sehingga siswa SGI 9 tidak dapat memenuhi indikator kerincian (Elaboration) dalam tes kemampuan berpikir kreatif matematis.

Hasil angket yang diberikan oleh peneliti kepada siswa SGI 9 berbanding terbalik dengan hasil tes kemampuan berpikir kreatif matematis, yaitu self-concept matematis siswa 
Analisis Kemampuan Berpikir Kreatif Matematis Ditinjau Dari Self-Concept Matematis Siswa, Siska Susilawati, Heni Pujiastuti, Sukirwan

SGI 9 termasuk kedalam katagori tinggi. Dari hasil angket self-concept matematis tergambarkan bahwa siswa SGI mempunyai penilai yang positif tentang kemampuan matematis yang dimilikinya serta mempunyai harapan yang positif mengenai kemampuan matematisnya. Kurangnya kemampuan siswa dalam memahami konsep yang berkaitan dengan materi bangun ruang datar dan mengembangkan ide yang dimiliki siswa menyebabkan siswa kesulitan dalam menyelesaikan suatu permasalahan yang diberikan.

\section{KESIMPULAN}

Pada penelitian sebelumnya yang dilakukan oleh Siti dan Chandra (2018) serta penelitian yang dilakukan oleh nurul dan luvy (2019) menyimpulkan bahwa self-concept matematis siswa sejalan dengan kemampuan berpikir kreatif matematis siswa atau dapat dikatakan bahwa self-concept matematis berbanding lurus dengan kemampuan berpikir kreatif matematis yang dimiliki siswa. Sedikit berbeda pada hasil penelitian yang telah dilakukan peneliti pada siswa kelas VIII MTsN 1 Kota Serang, terdapat siswa yang memliki self-concept matematis yang berbanding terbalik dengan hasil tes kemampuan berpikir kreatif matematisnya.

Dari analisis tes yang dilakukan peneliti dengan tingkatan self-concept matematis yang berbeda, diperoleh informasi yang lebih rinci mengenai permasalahan yang dihadapi siswa ketika diberikan soal berpikir kreatif matematis, di antaranya: (1) Terdapat siswa yang memliki self-concept matematis yang berbanding terbalik dengan hasil tes kemampuan berpikir kreatif matematisnya. 5 siswa yang mempunyai self-concept matematis tinggi namun hasil tes kemampuan berpikir kreatif matematisnya temasuk kedalam katagori 'kurang kreatif' dan 1 siswa yang mempunyai self-concept matematis rendah tetapi hasil tes kemampuan berpikir kreatifnya temasuk kedalam katagori 'kreatif'; (2) Dalam menerapkan strategi menyelesaikan masalah matematika siswa tidak terbiasa mengerjakan matematika dengan prosedur yang benar. Siswa mampu memecahkan masalah dengan baik, namun tidak disertai dengan penerapan prosedur yang tepat. Hal ini dikarenakan siswa tidak terbiasa dibimbing untuk memberikan langkah-langkah penyelesaian secara lengkap oleh guru mata pelajaran; (3) Beberapa siswa sering mengabaikan penulisan satuan pada hasil akhir jawaban, ada juga siswa yang salah menuliskan atau memasukan angka kedalam rumus yang digunakan. Hal ini dikarenakan siswa kurang teliti dalam pengerjaannya; (4) Beberapa siswa yang tidak teliti dalam mengerjakan soal-soal perhitungan yaitu operasi perkalian bilangan bulat, yang menyebabkan hasil akhir jawaban juga salah; (5) Siswa tidak maksimal dalam 
mengerjakan soal yang diberikan dikarenakan tidak terbiasa menerima permasalahan yang menuntut siswa untuk berpikir kreatif. Biasanya guru cenderung memberikan materi yang umum dan terpaku pada bahan ajar yang tersedia. Sehingga sebagian besar siswa tidak mampu menunjukkan kemampuan mereka dalam mengembangkan jawaban agar sesuai dengan aspek berpikir kreatif.

Kepada peneliti yang hendak mengambil penelitian yang sejenis, diharapkan dapat mengambil penelitian lanjutan berupa penelitian eksperimen dengan memberikan perlakuan yang bertujuan untuk memperbaiki self-concept matematis siswa untuk meningkatkan kemampuan berpikir kreatif matematis dan disarankan untuk memperhatikan kelemahankelemahan penelitian, terutama pada bagian penetapan instrumen penelitian agar diperoleh hasil yang lebih akurat.

\section{DAFTAR PUSTAKA}

Aisyah, N. S., \& Zanthy, L. S. (2018). ANALISIS KEMAMPUAN BERPIKIR KREATIF MATEMATIK DAN SELF CONCEPT SISWA MTs PADA MATERI HIMPUNAN. Journal On Education, 01(03), 252-259.

Calhoun, \& Acocella, D. (1995). Psikologi Tentang Penyesuaian Diri dan Hubungan Kemanusiaan (E. Terjemahan, Ed.). Semarang: IKIP Semarang Press.

Hanipah, N., Yuliani, A., \& Maya, R. (2018). Analisis Kemampuan Berpikir Kreatif Matematis Siswa MTs Pada Materi Lingkaran. Jurnal Pendidikan Matematika FKIP Univ. Muhammadiyah Metro, 7(1).

Hendriana, H., \& Rohaeti, E. E., \& Sumarmo, U. (2017). Hard Skill dan Soft Skill Matematik Siswa (1st ed.). Bandung: Refika Aditama.

Munandar, U. (2012a). Pengembangan Kreativitas Anak Berbakat. Jakarta: Rineka Cipta. Munandar, U. (2012b). Pengembangan Kreativitas Anak Berbakat. Jakarta: Rineka Cipta. Prihatiningsih, M., Ratu, N., Kristen, U., \& Wacana, S. (2020). Analisis tingkat berpikir kreatif siswa ditinjau dari gaya kognitif field dependent dan field independent 1,2. Jurnal Cendekia: Jurnal Pendidikan Matematika, 04(01), 353-364.

Rahman, R. (2012). Hubungan Antara Self-Concept Terhadap Matematika Dengan Kemampuan Berpikir Kreatif Matematik Siswa. InfinityJ Urnal Ilmiah Program Studi Matematika STKIP Siliwangi Bandung, 1(1), 19-30.

Rimlah, S., \& Novtiar, C. (2018). HUBUNGAN ANTARA SELF-CONCEPT TERHADAP KEMAMPUAN BERPIKIR KREATIF MATEMATIS SISWA MTSN 4 BANDUNG 
Analisis Kemampuan Berpikir Kreatif Matematis Ditinjau Dari Self-Concept Matematis Siswa, Siska Susilawati, Heni Pujiastuti, Sukirwan

BARAT. Nusantara of Research, 05(April), 9-15.

Salamor, R. (2013). Pembelajaran Group Investigation Dalam Upaya Peningkatan Kemampuan Berpikir Kritis dan Self Concept Matematis Siswa Sekolah Menengah Pertama. Retrieved November 11, 2019, from http://repository.upi.edu/ Simanjuntak, L. (2009). Metode Mengajar Matematika I. Jakarta: Rineka Cipta.

Sugiyono. (2017). Metode Penelitian Pendidikan (Pendekatan Kuantitatif, Kualitatif, dan $R N D)$. Bandung: Afabeta.

Supardi, \& Leonard. (2010). Pengaruh Konsep Diri, Sikap Siswa pada Matematika, dan Kecemasan Siswa Terhadap Hasil Belajar Matematika. FMIPA Universitas Indraprasta PGRI. Jurnal Cakrawala Pendidikan, 3(3). 